\title{
Multiple phosphorus acquisition strategies adopted by fine roots in low-fertility soils in Central Amazonia
}

\author{
Laynara F. Lugli (i) - Kelly M. Andersen • Luiz E. O. C. Aragão • Amanda L. Cordeiro • \\ Hellen F. V. Cunha $•$ Lucia Fuchslueger • Patrick Meir • Lina M. Mercado • Erick Oblitas • \\ Carlos A. Quesada • Jessica S. Rosa • Karst J. Schaap • Oscar Valverde-Barrantes • \\ Iain P. Hartley
}

Received: 1 July 2018 / Accepted: 25 January 2019/Published online: 22February 2019

(C) The Author(s) 2019

\begin{abstract}
Background and aims Ancient Amazon soils are characterised by low concentrations of soil phosphorus (P). Therefore, it is hypothesised that plants may invest a substantial proportion of their resources belowground to adjust their P-uptake strategies, including root morphological, physiological (phosphatase enzyme activities) and biotic (arbuscular mycorrhizal (AM) associations)
\end{abstract}

Responsible Editor: Felipe E. Albornoz.

Electronic supplementary material The online version of this article (https://doi.org/10.1007/s11104-019-03963-9) contains supplementary material, which is available to authorized users.

L. F. Lugli $(\bowtie) \cdot$ K. M. Andersen · L. E. O. C. Aragão • L. M. Mercado · I. P. Hartley

Geography, College of Life and Environmental Sciences, University of Exeter, Amory Building, Rennes Drive, Exeter, Devon EX4 4RJ, UK

e-mail: 1f313@exeter.ac.uk

e-mail: laynaralugli@gmail.com

K. M. Andersen · P. Meir

School of Geosciences, University of Edinburgh,

Edinburgh, UK

L. E. O. C. Aragão

National Institute for Space Research, Sao Jose dos Campos, Sao Paulo, Brazil adaptations. Since these strategies are energy demanding, we hypothesise that trade-offs between morphological traits and root phosphatase exudation and symbiotic associations would occur. Specifically, we expected that plants which invest in finer roots, and therefore have greater ability to explore large soil volumes, would have a high investment in physiological adaptations such as enhanced phosphatase production. In contrast, we

\author{
A. L. Cordeiro · H. F. V. Cunha • L. Fuchslueger • \\ E. Oblitas · C. A. Quesada - J. S. Rosa - K. J. Schaap • \\ O. Valverde-Barrantes \\ National Institute of Amazonian Research, Manaus, AM, Brazil \\ L. Fuchslueger \\ Department of Biology, Plants and Ecosystems, University of \\ Antwerp, Antwerp, Belgium \\ P. Meir \\ Research School of Biology, Australian National University, \\ Canberra, Australia \\ L. M. Mercado \\ Centre for Ecology and Hydrology, Wallingford, UK \\ O. Valverde-Barrantes \\ Department of Biological Sciences, Florida International \\ University, Miami, FL, USA
}


expected that plants with predominantly thicker roots would invest more in symbiotic associations, in which carbon is traded for $\mathrm{P}$ acquired from AM fungal communities.

Methods We collected absorptive roots ( $<2 \mathrm{~mm}$ diameter) from a lowland Central Amazon forest near Manaus, Brazil. We measured fine root diameter, specific root length (SRL), specific root area (SRA), root tissue density (RTD), root phosphatase activity (APase) and arbuscular mycorrhizal (AM) fungi colonisation.

Results Root morphological traits were related to APase activity, with higher APase activity in roots with higher SRL and SRA but lower RTD. However, the degree of AM colonisation was not related to any measured root morphological trait.

Conclusions Fine absorptive roots likely benefit from having low RTD, high SRL, SRA and APase exudation to acquire $\mathrm{P}$ efficiently. However, because AM colonisation was not related to root morphology, we suggest that investment in multiple P-uptake strategies is required for maintaining productivity in Central Amazon forests.

Keywords Amazon - Arbuscular mycorrhizas . Lowland tropical forest · Root phosphatase activity . Phosphorus limitation · Root morphology

$\begin{array}{ll}\text { Abbreviations } \\ \text { SRL } & \text { Specific root length } \\ \text { SRA } & \text { Specific root area } \\ \text { RTD } & \text { Root tissue density } \\ \text { APase } & \text { Root acid phosphomonoesterase } \\ \text { AM } & \text { Arbuscular mycorrhizas }\end{array}$

\section{Introduction}

Amazon forests are highly productive ecosystems, crucial for global carbon (C), nutrient and water cycling (Malhi et al. 2004) and C storage (Pan et al. 2011). Yet, about $60 \%$ of the soils in the Amazon Basin are characterised by concentrations of phosphorus $(\mathrm{P})$ and cations that are considered limiting to plant growth (Quesada et al. 2011). Phosphorus is used in an array of plant processes, including photosynthesis and respiration (Raghothama and Karthikeyan 2005; Vance et al. 2003), and, as a result, P availability in soils is usually considered to play an important role controlling growth rates in Amazon forests (Quesada et al. 2010, 2012). In young ecosystems, phosphorus is supplied to soil almost exclusively by the weathering of the parent material (Walker and Syers 1976), with small contributions from atmospheric deposition, varying greatly in space and time (Yu et al. 2015). Generally, during soil development, the importance of parent material as a source of nutrients declines considerably over time; total soil $\mathrm{P}$ concentration decreases due to weathering and leaching, and the remaining $\mathrm{P}$ pools become gradually more recalcitrant, adsorbed or occluded within mineral matrices and organic matter (Quesada et al. 2010; Tiessen et al. 1984; Walker and Syers 1976). Hence, over geological time scales, tropical forests become essentially dependent on the recycling of organic $\mathrm{P}$ from litter decomposition.

The concept of $\mathrm{P}$ limitation in tropical forests is widely accepted, but still, the mechanisms that allow Amazon forests to thrive in such P-poor environments are not clear. Plants can respond in two ways to overcome P limitation in soils: 1) increasing P-use efficiency aboveground, and/or 2) by improving P-uptake belowground (Kitayama 2013; Vitousek et al. 2010). Plants can enhance aboveground P-use efficiency by increasing the residence time of $\mathrm{P}$ within the canopy (Kitayama 2013; Kitayama and Aiba 2002; Kitayama et al. 2000; Vitousek 2004), maximising P resorption in leaves before senescence (Aerts 1996; Hayes et al. 2014; Raghothama and Karthikeyan 2005) or reducing or replacing $\mathrm{P}$ in essential compounds with other elements (Lambers et al. 2012; White and Hammond 2008). In addition to aboveground phosphorus efficient use, plants under low-fertility soils may be able to alter their root morphology and physiology, and/or vary their reliance on mycorrhizal fungi to optimise nutrient acquisition (Raghothama 1999; Richardson and Simpson 2011). Although belowground plant nutrient uptake mechanisms could be important contributors to tropical forest productivity (Bardgett et al. 2014), there is limited understanding of the role of different root traits in Puptake in tropical forests, especially in the Amazon.

Phosphorus is very immobile in soils, and for this reason roots preferentially move towards P (Aerts 1999). Root morphological traits, such as total root length, surface area and diameter directly control the efficiency by which $\mathrm{P}$ is assimilated by plants (Eissenstat 1992; Eissenstat and Yanai 1997), with small diameter roots being usually efficient at exploring large soil volumes (Bates and Lynch 2001; Hodge 2004; Liu et al. 2015). However, the only form of $P$ assimilated by plants and microorganisms is inorganic phosphate 
(mainly $\mathrm{PO}_{4}{ }^{-3}$ ), which is largely bound in organic compounds within tropical soils (Walker and Syers 1976). Consequently, these compounds cannot be directly taken up by plants and microorganisms and need to be degraded before being assimilated by roots (Lambers et al. 2006). The exudation of phosphatase enzymes (Hinsinger 2001; Olander and Vitousek 2000) and carboxylates (Jones and Oburger 2011; Lambers et al. 2015; Turner et al. 2012) are some of the mechanisms by which roots mobilise organic and inorganic occluded forms of $\mathrm{P}$ in soils. The main process through which organic P is hydrolysed in soils is via the activity of phosphatase enzymes released by microbes and plant roots (Hinsinger 2001; Olander and Vitousek 2000; Treseder and Vitousek 2001; Vance et al. 2003). Therefore, the coordination between small root diameter and large SRL and SRA together with phosphatase exudation may give fine roots a competitive advantage over thick roots by enabling them to explore the soil volume and mobilise organic P more efficiently (Kong et al. 2016; Liu et al. 2015).

Species with thick absorptive root systems, on the other hand, are not very efficient at nutrient foraging and are expected to preferentially invest in mycorrhizal associations to meet nutrient demands (Comas et al. 2014; Eissenstat et al. 2015; Kong et al. 2016). The very fine hyphal network typical of arbuscular mycorrhizas (AM) allow the fungi to acquire $\mathrm{P}$ away from $\mathrm{P}$-depleted zones around roots, resulting in high inorganic P-uptake in exchange for photosynthetically fixed $\mathrm{C}$ from the host plant (Eissenstat et al. 2015; Hodge 2004; Smith and Read 2010). In addition to their role in P uptake, AM fungi may also benefit plants by altering the microbial community in the rhizosphere, changing soil aggregation and/or decreasing plant susceptibility to pathogens (Herre et al. 2007; Koide 1991; Laliberte et al. 2015). Because of the multiple benefits that AM fungi confer to plants, this symbiotic association is extremely common and it is estimated that about $74 \%$ of all plants species are colonised by these fungi (Brundrett 2009; Smith and Read 2010).

Root morphological adaptations, as well as investment in phosphatase enzyme production and association with mycorrhizal fungi are, however, resource-costly (Jakobsen and Rosendahl 1990; McCormack et al. 2015; Treseder and Vitousek 2001). For instance, the construction of fine acquisitive roots might require less $\mathrm{C}$ per unit root length but these roots also display higher rates of respiration and faster turnover when compared to coarser roots (Laliberte et al. 2015; McCormack et al. 2015). Mycorrhizal fungi can receive up to $25 \%$ of $C$ assimilated by plants (Jakobsen and Rosendahl 1990) and root exudates can represent up to half of belowground $\mathrm{C}$ allocation (Lynch and Ho 2005). As a result, it has been suggested that many plants do not invest energy in multiple nutrient-acquisition mechanisms, but rather show a trade-off between one strategy at the expense of another (Nasto et al. 2017; Ryan et al. 2012; Ushio et al. 2015). One such trade-off in nutrient foraging strategies between thin and thick absorptive roots has been shown for a few plant species (Chen et al. 2016; Ushio et al. 2015) but the generality of such a mechanism at the ecosystem-level has yet to be tested.

Since the role of fine roots in forest functioning in Amazonia is poorly understood, this study aims to describe root strategies used by plants to overcome Plimitation in Central Amazonia, testing for possible trade-offs between alternative strategies. To address this we investigated root morphological traits represented by root diameter $(\mathrm{mm})$, specific root length $\left(\mathrm{cm} \mathrm{mg}^{-1}\right)$, specific root area $\left(\mathrm{cm}^{2} \mathrm{mg}^{-1}\right)$ and root tissue density $\left(\mathrm{mg} \mathrm{cm}{ }^{-3}\right.$ ), as well as root phosphatase activity and association with arbuscular mycorrhizal fungi. Our hypothesis was that under similar environmental conditions, a trade-off between resource investment in root morphological traits and P-uptake strategies would occur, with different predominant P-uptake strategies being associated with roots of different morphologies. We would therefore expect that root phosphatase activity (APase) should be negatively correlated with root diameter and RTD, but positively correlated with SRL and SRA and that AM colonisation should correlate positively with root diameter and RTD and negatively with SRL and SRA. Under an alternative scenario, we hypothesised the lack of such a trade-off because of the very low $\mathrm{P}$ availability in soils and/or the many potential roles that AM fungi could play, resulting in roots investing in multiple P-uptake mechanisms independently of their morphology.

\section{Material and methods}

\section{Study site description}

This study was carried out in the Cuieiras Reserve at ZF2, ca. $60 \mathrm{~km}$ north of Manaus, Amazonas, Brazil, maintained by the National Institute of Amazonian 
Research (INPA). The vegetation is an old growth, terra firme lowland forest with mean air temperature of $26^{\circ} \mathrm{C}$ and mean annual precipitation around $2400 \mathrm{~mm}$ (Araújo 2002). The plots at the study site are characterised by high species diversity and the soils are classified as Ferralsols (World Reference Base for Soil Resources, 2006), with soil $\mathrm{pH}$ (in $\mathrm{H}_{2} \mathrm{O}$ ) ranging from 4 to 4.7. The soils in our study area show particularly low P concentrations in relation to other soils across the Amazon basin (Quesada et al. 2010, 2011), being on the low range of fertility for Amazon soils. For instance, total $\mathrm{P}$ in the top $10 \mathrm{~cm}$ of soil along the basin varies from 29 to $968 \mathrm{mg} \mathrm{kg}^{-1}$ (Quesada et al. 2010), with total $P$ in our study site varying from 118 to $217 \mathrm{mg} \mathrm{kg}^{-1}$ in the same soil horizon (Table 1 and Table S1, online resources; methodology as described in the online resources).

We sampled 32 plots, measuring $40 \mathrm{~m} \times 40 \mathrm{~m}$, established in areas with similar soil, vegetation and terrain (all plateaus), with plots at least $50 \mathrm{~m}$ away from each other. The similar environmental conditions and consistently low-P concentrations in soils across the plots allowed us to investigate the extent to which, under similar soil conditions, different P-uptake strategies are used by plants at the ecosystem level. Due to the small variation in soil fertility among plots in our study site,

Table 1 Soil total P and soil P fractions following Hedley et al. (1982) methodology (details are in online resources)

\begin{tabular}{lllll}
\hline & Mean & SD & Minimum & Maximum \\
\hline Resin P & 4.46 & 0.94 & 2.59 & 6.44 \\
Bicarbonate Pi & 1.33 & 0.59 & 0.39 & 2.51 \\
Bicarbonate Po & 6.07 & 1.49 & 3.73 & 10.26 \\
Hydroxide Pi & 15.76 & 2.25 & 11.27 & 20.73 \\
Hydroxide Po & 15.27 & 2.79 & 9.27 & 19.09 \\
HCl P & 1.20 & 0.32 & 0.75 & 2.26 \\
Residual P & 104.4 & 17.6 & 68.9 & 166.7 \\
Total P & 148.4 & 19.3 & 118.5 & 217.4 \\
Readily available P & 11.86 & 1.95 & 7.84 & 16.22 \\
Total extractable P & 44.09 & 4.79 & 32.73 & 53.87 \\
\hline
\end{tabular}

Values represent mean $( \pm \mathrm{SD})$ and ranges for each $\mathrm{P}$ fraction $\left(\mathrm{mg} \mathrm{kg}^{-1}\right)$ extracted from all plots $(n=32) . \mathrm{Pi}=$ inorganic $\mathrm{P} ; \mathrm{Po}=$ organic P. P fractions are shown in decreasing order of availability, with resin $\mathrm{P}$ being the most available fraction and residual $\mathrm{P}$ being the least available. Total $\mathrm{P}$ is the sum of all fractions; readily available $\mathrm{P}$ is calculated as the sum of resin $\mathrm{P}$ and bicarbonate $\mathrm{Pi}$ and Po (fractions that are very to moderately available for plants); total extractable $\mathrm{P}$ is calculated as the sum of all fractions except residual $\mathrm{P} . \mathrm{SD}=$ standard deviation relationships between soil $\mathrm{P}$ concentrations and root traits are only briefly discussed and are shown in Fig. S1 (online resources).

\section{Root sampling}

Freshly produced fine-roots were sampled in May, 2016 using the ingrowth core technique (Metcalfe et al. 2007). In each plot $(n=32)$, five $12 \mathrm{~cm}$-diameter, $30 \mathrm{~cm}$-deep, root-free ingrowth cores $(2 \mathrm{~cm}$ plastic mesh bag) were installed in JanuaryFebruary 2016 in the central $20 \mathrm{~m} \times 20 \mathrm{~m}$ plot area. Ingrowth cores were collected after 3-4 months of installation and all fine roots were manually extracted and root-free soil reinserted into the existing holes (Metcalfe et al. 2007). Root samples were divided by depth $(0-5,5-10,10-20$ and $20-30 \mathrm{~cm})$ and cleaned by removing soil particles. Fine roots are usually defined as $\leq 2 \mathrm{~mm}$ in diameter, but because we sampled relatively young roots $(<4$ months old $)$, our samples represented only first to third order roots, as classified by Pregitzer et al. (2002). We therefore defined these roots by their function as absorptive fine roots, directly involved in nutrient uptake (McCormack et al. 2015). We restricted our analyses for subsamples from the $0-10 \mathrm{~cm}$ depth interval, since the majority of roots were found in the top $10 \mathrm{~cm}$ soil layer. Five replicate cores were combined per plot $(n=32)$ and subsamples were analysed for mycorrhizal colonisation and fine root acid phosphatase activity (APase). Another subsample was scanned for morphology analysis and then dried at $60{ }^{\circ} \mathrm{C}$ to determine dry root mass. Root productivity was calculated as dry mass of roots $(\mathrm{mg})$ produced per day for the top $10 \mathrm{~cm}$ soil layer.

\section{Root morphology}

Root samples from the $0-10 \mathrm{~cm}$ layer were scanned twice to determine root morphological traits. First an image was obtained with all roots from the sample, subsequently, some root fragments were picked to analyse for mycorrhizal colonisation and the sample was scanned again to generate a second image on which root fragments used for AM analysis were absent. The morphological traits for the fragments used for AM analysis (methodology as described in the online resources) were calculated using the difference between the two scanned images. In addition, another small subsample of root tips 
were used for the enzyme assay and scanned separately. All images were scanned at $600 \mathrm{dpi}$ and analysed using WinRHIZO (WinRHIZO Regular, Regent Instruments, Canada) to determine specific root length (SRL), specific root area (SRA), root tissue density (RTD) and mean root diameter (Metcalfe et al. 2008). SRL $\left(\mathrm{cm} \mathrm{mg}^{-1}\right)$ was calculated as the length per unit root dry mass; SRA $\left(\mathrm{cm}^{2} \mathrm{mg}^{-1}\right)$ was calculated as root superficial area per unit dry mass; RTD $\left(\mathrm{mg} \mathrm{cm}^{-3}\right)$ was calculated as root dry mass per unit root volume. With these three sets of root morphological measurements we were able to discuss general morphological traits at plot and ecosystem level but also look at correlations between the root morphological traits, AM colonisation and APase activity.

\section{Root phosphatase activity}

Potential root acid phosphomonoesterase activity (APase) was measured for roots from 0 to $10 \mathrm{~cm}$ soil depth $(n=32)$ using a fluorimetric microplate assay adapted following protocols by German et al. (2011) and Turner and Romero (2010). All clean root samples were kept refrigerated $\left(4^{\circ} \mathrm{C}\right)$ to avoid tissue degradation and enzyme activities were measured within 2 weeks of root sampling using triplicate subsamples per plot. About $10 \mathrm{mg}$ of each root sample (washed, fresh weight basis) were placed into a sterile $2 \mathrm{ml}$ Eppendorf snapcap vial with $1 \mathrm{ml}$ of buffer and $0.25 \mathrm{ml}$ of Methylumbelliferyl-phosphate (MUF-phosphate; $2 \mathrm{mM}$ ). A further identical root sample was prepared as a control by adding $1.25 \mathrm{ml}$ of buffer. In addition, buffer blanks $(n=3)$ and substrate blanks $(n=3)$ were prepared as $1.25 \mathrm{ml}$ of buffer (no roots, no substrate) and $1 \mathrm{ml}$ of buffer $+0.25 \mathrm{ml}$ of MUF-phosphate (no roots), respectively. Samples were incubated for $30 \mathrm{~min}$ at $\sim 25^{\circ} \mathrm{C}$ while gently shaking, then $50 \mu \mathrm{L}$ of $1 \mathrm{M} \mathrm{NaOH}$ were added to all samples and standard vials to terminate the reactions. Aliquots of the sample solution were pipetted into a black 96-well microplate and $20 \mathrm{~min}$ post termination, fluorescence was read on a fluorometer (Tecan Infinite® 200 PRO, Grödig, Austria), at $365 \mathrm{~nm}$ excitation and $450 \mathrm{~nm}$ emission. Roots were then removed from vials, rinsed with Milli-Q water and dried at $60{ }^{\circ} \mathrm{C}$ for $72 \mathrm{~h}$. Root APase activity per plot is represented in nmol MUF $\mathrm{mg}^{-1}$ dry root mass $\mathrm{h}^{-1}$. Based on the images from the scanned root subsamples, root APase activity was also calculated per $\mathrm{cm}$ root length and $\mathrm{cm}^{2}$ root area (online resources, Table S2).
Mycorrhizal colonisation

To determine AM colonisation, root samples from the 0 $10 \mathrm{~cm}$ soil depth were cleaned and segments of fresh absorptive roots from the first three orders were cut and stored in 50\% ethanol. Samples were then transferred to small cassettes and if needed, subsamples were separated by colour/appearance: dark roots, red/brown and clear roots. The clearing and staining processes, designed to highlight only the mycorrhizal structures, were adapted to tropical roots based on Brundrett et al. (1984) and Wurzburger and Wright (2015). The cassettes were placed in a $2.5 \% \mathrm{KOH}$ solution and autoclaved at $120{ }^{\circ} \mathrm{C}$ for $\sim 10 \mathrm{~min}$, with processing time depending on the darkness of the roots. If roots were still darkly pigmented after the clearing process, they were placed in alkaline $\mathrm{H}_{2} \mathrm{O}_{2}$ solution for further bleaching for 30 min, checking them constantly so no material was lost due to over clearing or bleaching. Before staining, roots were acidified by placing cassettes in $2 \% \mathrm{HCl}$ solution for $30 \mathrm{~min}$ and then were added to a beaker with Trypan Blue $0.05 \%$ for $30 \mathrm{~min}$. When consistently blue, roots were rinsed well and stored in distilled water in the fridge $\left(4^{\circ} \mathrm{C}\right)$ for slide preparation. The time between root staining and AM colonisation analysis never exceeded 2 weeks. Roots were placed in rows across the length of the slide and fixed using polyvinyl alcohol (PVA). To quantify mycorrhizal colonisation, 50-100 intersections per sample were read using the microscope micrometer (vertical cross-hair) to analyse the sections (McGonigle et al. 1990). At each intersection the colonisation was scored according to the following categories: no mycorrhizal structures, hyphae only, hyphae + arbuscules, hyphae + vesicles, hyphae + vesicles + arbuscules. Mycorrhizal colonisation was assessed as the percentage of the total root intersections along the root length that had mycorrhizal fungi. Only total AM colonisation (sum of colonisation by hyphae, arbuscules and vesicles) is discussed in detail in the results, and colonisation by each AM fungal structure is shown in Table S2 (online resources).

\section{Statistical analyses}

Linear models were used to test for the influence of soil $\mathrm{P}$ fractions on root traits. Bivariate relationships between root morphology properties, root phosphatase activity and AM colonisation were described using Standard Major Axis (SMA) line fits using the package 
smatr (Warton et al. 2012; Warton et al. 2006). Standard Major Axis analysis is generally used in plant allometry studies when there is no clear causation among the variables tested. By using the SMA test, we aimed to estimate the line of best fit between traits, taking into account inherent error associated with both axes. All statistical analyses were conducted in $\mathrm{R}$ version 3.3.3. (R Core Team 2017).

\section{Results}

Root traits variation

Despite the common soil conditions in our study site (Table 1 and Table S1, online resources), we found marked variation in root morphology (Table 2 and Table S2, online resources), however, no significant relationships between soil $\mathrm{P}$ fractions and root traits were observed, with the exception of a positive relationship between bicarbonate $\mathrm{Pi}$ (one of the most readily available forms of P) and RTD (Fig. S1, online resources). Correlations between root morphological traits are not discussed here but are shown in Figs. S24 in the online resources for each set of morphological data. Fine root diameter varied from 0.39 to $1.1 \mathrm{~mm}$, with RTD displaying a three-fold variation, ranging from 141.78-419.22 $\mathrm{mg} \mathrm{cm}^{-3}$ (Table 2 and Table S2, online resources). Specific root area and root APase activity showed a four-fold variation, varying from $0.14-0.56 \mathrm{~cm}^{2} \mathrm{mg}^{-1}$ and $15-66 \mathrm{nmol} \mathrm{mg}^{-1} \mathrm{~h}^{-1}$ respectively. Among all traits measured, SRL was the most variable, ranging from 0.59 to $4.15 \mathrm{~cm} \mathrm{mg}^{-1}$. All sampled roots showed some degree of AM colonisation, ranging between 10 to $80 \%$ of root length colonised by AM, with an average of $44.31 \%$ (Table 2 and Table S2, online resources).

Relationship between root morphological properties and P-uptake strategies

Root morphological traits were found to be related to the levels of root APase activity (Fig. 1). Root APase activity decreased with increasing RTD $(\mathrm{r}=0.14, P=0.035)$, and increased with increasing SRL $(r=0.16, P=0.02)$ and SRA ( $\mathrm{r}=0.25, P=0.003)$, with no significant relationship between root APase and root diameter (Fig. 1a). In contrast, no relationship between total AM colonisation levels and root morphological traits was found, as shown in Fig. 2 (correlations between root morphological traits and AM colonisation by different fungi structure are not discussed here but are shown in Fig. S5).

\section{Trade-offs between root P-uptake strategies}

Since root morphological traits were found to influence root APase activity but not AM colonisation, the existence of a trade-off between both root P-uptake strategies was not supported by our results. This is further demonstrated by the lack of a clear relationship between APase activity and AM colonisation (Fig. S6 and S7, online resources) although it should be noted that it was

Table 2 Root productivity, morphological, physiological and biotic properties from 32 plots in a Central Amazon forest

\begin{tabular}{lllll}
\hline & Mean & SD & Minimum & Maximum \\
\hline Root productivity $\left(\mathrm{mg} \mathrm{day}^{-1}\right)$ & 7.85 & 2.83 & 2.77 & 16.01 \\
SRL $\left(\mathrm{cm} \mathrm{mg}^{-1}\right)$ & 2.09 & 0.78 & 0.59 & 4.15 \\
SRA $\left(\mathrm{cm}^{2} \mathrm{mg}^{-1}\right)$ & 0.33 & 0.08 & 0.14 & 0.56 \\
RTD $\left(\mathrm{mg} \mathrm{cm}^{-3}\right)$ & 239.47 & 59.28 & 141.78 & 419.22 \\
Diameter $(\mathrm{mm})$ & 0.69 & 0.21 & 0.39 & 1.11 \\
APase $(\mathrm{nmol} \mathrm{mg}$ & $\left.15 \mathrm{~h}^{-1}\right)$ & 14.59 & 15.46 & 65.98 \\
AM colonisation $(\%)$ & 36.05 & 16.57 & 10.17 & 80.95 \\
\hline
\end{tabular}

Values represent means and ranges for each root trait. $\mathrm{SRL}=$ specific root length $\left(\mathrm{cm} \mathrm{mg}^{-1}\right)$; SRA $=$ specific root area $\left(\mathrm{cm}^{2} \mathrm{mg}^{-1}\right) ; \mathrm{RTD}=$ root tissue density $\left(\mathrm{mg} \mathrm{cm}^{-3}\right)$, APase $=$ acid phosphatase activity $\left(\mathrm{nmol} \mathrm{mg} \mathrm{m}^{-1} \mathrm{~h}^{-1}\right)$ and AM colonisation $=$ arbuscular mycorrhizal fungi colonisation (\%). SD = standard deviation. Mean root morphological data (diameter, SRL, SRA and RTD) and root productivity are from the whole ingrowth core sample. APase activity and AM colonisation were determined in roots subsampled from the total ingrowth core sample. All measurements, with the exception of AM colonisation and diameter, are shown in root dry weight basis 

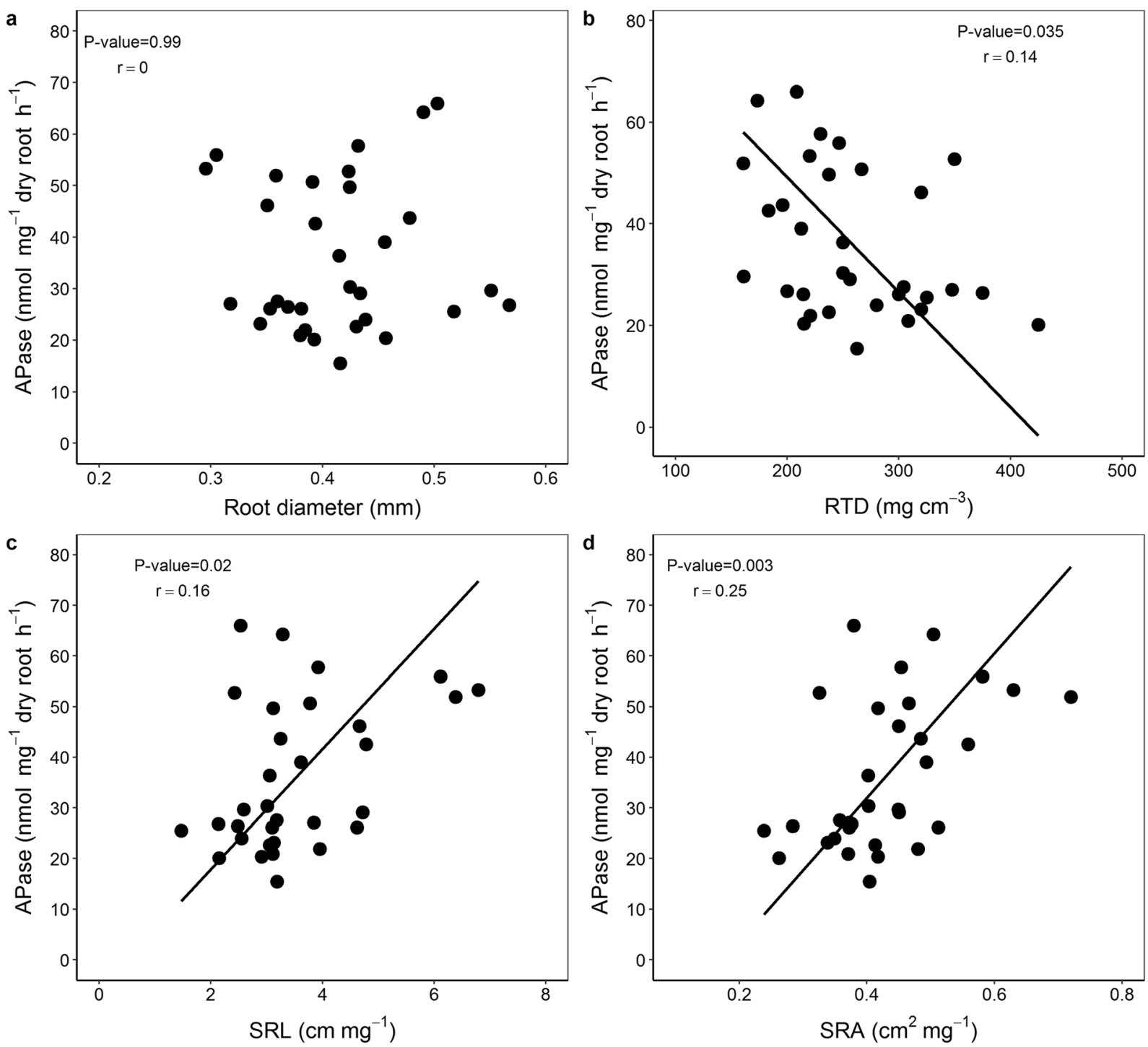

Fig. 1 Standardised major axis (SMA) relationships between root phosphatase activity and root morphological properties. Each dot represent a mean of root traits per plot $(0-10 \mathrm{~cm}$ soil depth) extracted from ingrowth cores (ecosystem level measurement).

APase $=$ acid phosphatase activity $\left(\mathrm{nmol} \mathrm{mg}^{-1}\right.$ dry root $\left.\mathrm{h}^{-1}\right)$; $\mathrm{SRL}=$ specific root length $\left(\mathrm{cm} \mathrm{mg}^{-1}\right)$; SRA $=$ specific root area $\left(\mathrm{cm}^{2} \mathrm{mg}^{-1}\right)$; RTD = root tissue density $\left(\mathrm{mg} \mathrm{cm}^{-3}\right)$. Solid lines indicate significant relationships $(P<0.05)$

not possible to carry out the enzyme and mycorrhizal assays on the same root subsamples.

\section{Discussion}

Fine root traits are often reported to reflect plant efficiency in acquiring the most limiting soil nutrients (Lambers et al. 2006; Raghothama 1999). Based on a presumed trade-off in energy investments between root trait adaptations to improve $\mathrm{P}$-uptake, we aimed to test if

in Central Amazon forests plants would also preferentially display one dominant root P-uptake strategy. Despite the similar topography and the relatively narrow variation in $\mathrm{P}$ availability in our study site, root traits did not converge towards a single P-uptake strategy but rather displayed multiple complementary strategies to overcome apparent P limitation. We therefore suggest that the variations in root traits found in this Central Amazon forest reflect the dominant features of a much larger diversity of adaptations displayed by different plants in low fertility soils. 

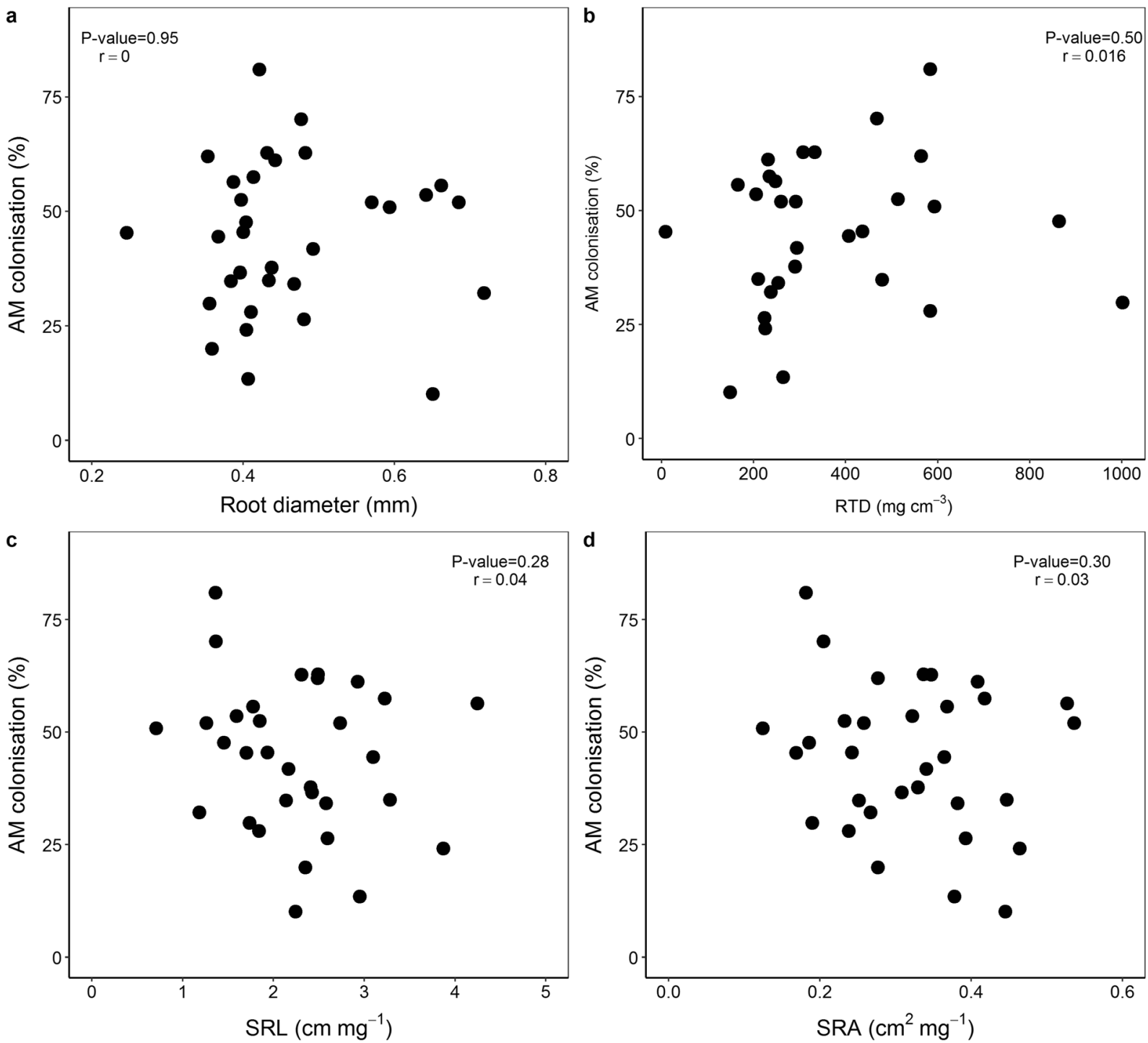

Fig. 2 Standardised major axis (SMA) relationships between total root AM colonisation (\% of root length) and root morphology properties. Each dot represent a mean of root traits per plot $(0-$



$10 \mathrm{~cm}$ soil depth) extracted from ingrowth cores (ecosystem level measurement). SRL $=$ specific root length $\left(\mathrm{cm} \mathrm{mg}^{-1}\right)$; SRA $=$ specific root area $\left(\mathrm{cm}^{2} \mathrm{mg}^{-1}\right) ; \mathrm{RTD}=$ root tissue density $\left(\mathrm{mg} \mathrm{cm}^{-3}\right)$

Variation in root morphology

Although we found SRL and SRA varying across plots, our mean values were similar to the ones found by Metcalfe et al. (2008) in a clay-rich Ferralsol in Para, Brazil. Also using the ingrowth core technique, these authors found SRL varying from 1 to $3.5 \mathrm{~cm} \mathrm{mg}^{-1}$ and SRA varying from 0.25 to $1.5 \mathrm{~cm}^{2} \mathrm{mg}^{-1}$ during a yearround sampling campaign, while our mean values for one sampling interval (3-4 months) were $2.09 \mathrm{~cm} \mathrm{mg}^{-1}$ and $0.33 \mathrm{~cm}^{2} \mathrm{mg}^{-1}$ for SRL and SRA, respectively.

Wurzburger and Wright (2015) reported mean values of $1.5 \mathrm{~cm} \mathrm{mg}^{-1}$ for SRL and $150 \mathrm{mg} \mathrm{cm}^{-3}$ for RTD at a site in Panama, but this was based on measurements made on standing stocks rather than in ingrowth cores. Additionally, Kong et al. (2014) also using standing stock cores, found mean SRL and RTD of $5.6 \mathrm{~cm} \mathrm{mg}^{-1}$ and $358.5 \mathrm{mg} \mathrm{cm}^{-3}$ respectively for trees at a subtropical site in China, contrasting with $2.09 \mathrm{~cm} \mathrm{mg}^{-1}$ and $239.47 \mathrm{mg} \mathrm{cm}^{-3}$ found in this study. The data reported here and from other studies in tropical forests are, however, not directly comparable because of 
the difference in methods used (ingrowth core versus standing stock biomass). We aimed to investigate young, absorptive roots, making ingrowth cores the most appropriate method for our study, but further research on established root systems in future studies would also be valuable.

Relationship between root morphology and phosphatase activity

We hypothesised that root phosphatase activity would be related to root morphological traits, with higher APase activity in roots with smaller diameter and lower tissue density and therefore higher SRL and SRA. Although our samples refer to plot means at the ecosystem level, we found partial support for the first hypothesis, since three of the four root morphological traits analysed here were correlated as expected with APase activity, with the exception of root diameter. Our results confirm the findings of Ushio et al. (2015) who found lower APase activity with increasing RTD, and higher APase activity with increasing SRA at the species level in tropical montane forests in Borneo. However, Ushio et al. (2015), studying fine roots up to $2 \mathrm{~mm}$ diameter, reported that APase activity was negatively correlated with root diameter, whilst no such relationship was found in this study. The lack of a significant relationship between root diameter and APase found here could be due to the small variation in root diameter from our root subsamples (0.29$0.57 \mathrm{~mm}$; Fig. 1a), since only first order acquisitive roots were analysed.

A decline in RTD with increasing APase could be seen as a strategy to maximise belowground biomass investment per root volume (Eissenstat 1992) thereby reserving energy for phosphatase exudation and consequently P-uptake. Despite the low C-costs of construction, fine roots have higher costs of maintenance when compared to coarse roots, displaying high rates of respiration and turnover (Eissenstat and Yanai 1997; McCormack et al. 2015). For instance, because of their lower mechanical strength, fine roots are more susceptible than coarse roots to the attack of soil-borne pathogens and herbivores (Laliberte et al. 2015; Ushio et al. 2015). The high investment in producing roots with high SRA and SRL associated with high risks of carbon loss could be compensated by high-P acquisition resulting from higher APase activity (Ushio et al. 2015). Because samples in this study represent many different plant species, correlation coefficient values obtained for APase activity and morphological traits were low, but despite the species-specific noise, our analysis still captures the dominant signal on the relationships tested at the ecosystem level. Nevertheless, our results suggest that investing in fine long roots and APase exudation seem to be an efficient P-uptake mechanism, possibly overcoming the potential costs of root maintenance.

The efficiency of plants in acquiring $\mathrm{P}$ generally increases under $\mathrm{P}$ limitation and therefore, higher root APase activity is usually found in soils with lower P concentrations (Kitayama 2013; Raghothama and Karthikeyan 2005). Root APase activity at our site

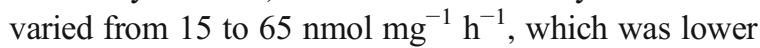
than the values found in a montane forest in Borneo (100-200 $\mu \mathrm{mol} \mathrm{pNPP} \mathrm{g}^{-1} \mathrm{~h}^{-1}$; note that nmol mg ${ }^{-1} \mathrm{~h}^{-1}$ and $\mu \mathrm{mol} \mathrm{g}{ }^{-1} \mathrm{~h}^{-1}$ are equivalent units) (Kitayama 2013; Ushio et al. 2015) but higher than root APase activity found in plants associated with AM in Panama $(10 \mu \mathrm{mol}$ pNPP $\mathrm{g}^{-1} \mathrm{~h}^{-1}$ ) (Steidinger et al. 2015) and also higher than in forests in Costa Rica (5-12 $\mu$ mol 4-MUF $\mathrm{g}^{-1} \mathrm{~h}^{-1}$ ) (Nasto et al. 2014, 2017). Total soil P concentrations in forests in Borneo were very low, ranging from 10 to $60 \mathrm{mg} \mathrm{kg}^{-1}$, which could explain the higher investment of plants in root APase activity reported by Kitayama (2013) and Ushio et al. (2015). In addition, litter decay rates and consequently organic $P$ mineralisation is slower in montane forests because of the lower temperatures (Grubb 1977; Vitousek and Sanford 1986), which could also translate into higher phosphatase exudation in Borneo. On the other hand, total $\mathrm{P}$ concentrations in soils in Costa Rica (665$1600 \mathrm{mg} \mathrm{kg}^{-1}$ ) (Nasto et al. 2014), were much higher than those found in this study (118-227 $\left.\mathrm{mg} \mathrm{kg}^{-1}\right)$. Thus, the low root APase activity in Costa Rica and Panama could therefore suggest that (1) Central American forests are not as P-limited as the Central Amazon forests studied here or (2) the greater $\mathrm{P}$ availability allows plants in these Central American forests to invest in Puse/acquisition strategies other than APase activity.

We present some of the first root phosphatase data from Central Amazon forests, with assays undertaken on roots that were stored for 2 weeks prior to analysis. While 2 weeks of storage has been used in studies of enzyme activities in tropical soils (Turner and Romero 2010), it would be useful to carry out further investigations into whether storage time or storage conditions affect root phosphatase measurements on tropical roots. 
Such tests would help us to evaluate and compare our potential activity values further and to develop methodological recommendations to be employed in future research. Nonetheless, our results still represent real differences among plots, once all the samples received the same treatment.

Relationship between root morphology and total mycorrhizal colonisation

We also hypothesised that thick, dense and short absorptive roots would have higher AM colonisation than small diameter roots. Despite substantial variation in root morphological traits, no significant relationships were observed between AM colonisation and the other root traits, irrespective of whether relationships with total mycorrhizal colonisation rates (Fig. 2) or rates of colonisation by different AM structures (arbuscules, vesicles, hyphae; see supplementary material) were investigated. Total AM root colonisation in our site ranged from 10 to $80 \%$, with a mean of $44 \%$, whilst earlier studies have shown that AM colonisation in Brazilian native woody species could range from absent to about $80 \%$ in different levels of soil-P (Siqueira and SagginJúnior 2001). Apart from soil conditions, root development (length, diameter, root hair density and nutrientuptake capacity), environmental characteristics (soil nutrient availability, plant competition, soil microbial biota, soil depth, seasonality) and fungal hyphae properties (root colonisation rate, growth rate and nutrient-uptake capacity) have all been reported to influence AM colonization (Hoeksema et al. 2010; Johnson 2010; Li et al. 2017; Smith et al. 2011). Evidence for the positive correlation between root diameter and AM colonisation exists for some species in Central Amazon (St John 1980), but it is possible that relationships at the ecosystem level may be different or harder to detect.

Various studies have suggested that fine and thick absorptive roots display different strategies for nutrient acquisition, with thin roots depending on directly acquiring nutrients and thicker roots depending more on mycorrhizal fungi (Chen et al. 2016; Eissenstat et al. 2015; Kong et al. 2016; Liu et al. 2015). The absence of a significant relationship between AM colonisation and root morphological traits found in this study was also reported for Brazilian native woody species studied under greenhouse conditions (Siqueira and SagginJúnior 2001) and in a meta-analyses of studies with plants from different biomes (Maherali 2014). Siqueira and Saggin-Júnior (2001) and Maherali (2014) reported certain coarse-root tree species being completely AM-independent, whereas other species with small root diameter showed high AM colonisation. Arbuscular mycorrhizal fungi form associations within root cortical cells only, and for this reason, root diameter does not necessarily represent an appropriate proxy for mycorrhizal colonisation (Brundrett 2002; Comas et al. 2014; Guo et al. 2008). For roots with similar diameters, those with a greater cortex to stele ratio, are usually expected to support higher AM colonisation (Kong et al. 2017; Valverde-Barrantes et al. 2016). Therefore, differences in key root properties between species may obscure relationships between diameter and colonisation rates. Other relevant properties of roots, such as root architecture (e.g. branching frequency, root hair density and length), could also change in response to AM colonisation (Maherali 2014), but were beyond the scope of this study. As an alternative, there is evidence suggesting that plants lack efficient mechanisms to control AM colonization (Johnson 2010; Valverde-Barrantes et al. 2016), meaning that all root cortical tissues created could be potentially colonized independently of $\mathrm{P}$ availability. Furthermore, the relative importance of internal AM structures versus extraradical hyphae for nutrient foraging is still not completely understood (Smith and Read 2010), and since we did not sample soil hyphae we assumed that the percentage of internal colonisation was a proxy for $\mathrm{P}$ uptake.

Trade-off between root P-uptake strategies and the consequences for ecosystem functioning under P-limitation

Investment in nutrient acquisition by plants demands the allocation of other resources, such as $\mathrm{C}$ and nitrogen $(\mathrm{N})$ (Nasto et al. 2017). For instance, it has been suggested that mycorrhizal fungi can receive up to $25 \%$ of $\mathrm{C}$ assimilated by plants (Jakobsen and Rosendahl 1990) and root exudates can represent up to half of belowground $\mathrm{C}$ allocation (Lynch and Ho 2005). In addition, the $\mathrm{N}$ costs of P-uptake via APase activity could range between 1 to $16 \mathrm{~g} \mathrm{~N}$ per $\mathrm{g}$ of P (Treseder and Vitousek 2001). Based on the possible resource costs of investing in multiple P-uptake strategies simultaneously, we hypothesised the existence of a tradeoff between APase activity and AM colonisation (Nasto et al. 2017). However, because only APase activity was related to root morphological traits with no influence on 
AM colonisation, we can infer that these two strategies were not negatively correlated as we hypothesised, suggesting that at the ecosystem level there is not a trade-off between these P-uptake mechanisms at our study site.

Since $\mathrm{P}$ in tropical soils is largely bound in organic compounds or occluded in secondary minerals (Cross and Schlesinger 1995) that need to be hydrolysed prior to plant uptake, we would expect root APase activity to play a major role in $\mathrm{P}$ cycling in this Central Amazon forest if compared to the role of AM fungi. The average level of AM root colonisation in our site was $44 \%$, lower than compared to the $70 \%$ AM colonisation observed in nutrient-rich soils in Panama (Wurzburger and Wright 2015). However, independent of root morphology, all plots in our study site displayed moderate levels of AM colonisation, suggesting that besides improving inorganic $\mathrm{P}$ uptake, AM association could play other roles. Arbuscular mycorrhizal fungi could benefit plants by increasing the uptake of micronutrients (e.g. zinc, copper), change the microbial community in the rhizosphere, increase plant chemical defence against pathogens and herbivores (Herre et al. 2007; Koide 1991; Laliberte et al. 2015) and also possibly by influencing phosphatase production by plants (Joner et al. 2000; Nasto et al. 2014). Fine roots are more susceptible to soil pathogen and herbivore attack (Laliberte et al. 2015) and the potential role of AM increasing plant defence could therefore explain why small diameter roots were found to be colonised by AM in our study site. The multiple functions of AM fungi associating with roots could also obscure the relationship between AM colonisation rates and $\mathrm{P}$ uptake.

Additionally, the lack of correlation (neither negative nor positive) between AM colonisation and root APase could suggest the possible complementary role of both strategies (Steidinger et al. 2015; Turner 2008). In this scenario, roots would benefit by investing in both strategies at the same time, since AM fungi and APase are known to explore different forms of $\mathrm{P}$ in soils: roots release phosphatase enzymes to mineralise organic $\mathrm{P}$ whilst AM fungi could benefit plants by exploiting inorganic $\mathrm{P}$ pools that do not need to be hydrolysed by enzymes or, more importantly, that have already been released by phosphatase enzymes (Nasto et al. 2014). This mechanism may be of special importance for fine absorptive roots in our study site, which displayed intermediate levels of AM colonisation and phosphatase exudation. This could also suggest that fine roots with high
SRL and SRA may still not ensure adequate nutrient supply for some species in low fertility soils in the tropics, making them also dependent on AM (Siqueira and Saggin-Júnior 2001).

Investing in both enzyme production and AM association at the same time could also suggest that plants have access to enough resources, such as $\mathrm{C}$ and $\mathrm{N}$, to support both strategies. In addition, mechanisms such as the exudation of organic acid/anions by roots could be an important plant reaction under P deficiency (Aoki et al. 2012; Lambers et al. 2006), but were not analysed in our study. Since our measurements were made at the ecosystem level, we were not able to analyse the individual relationships between root morphology, phosphatase activity and AM colonisation at the species level and therefore our interpretations could be different if we could control for host species. For instance, not all tree species have the same $\mathrm{P}$ requirements and $\mathrm{P}$-use-efficiencies and therefore the investment in strategies to scavenge $\mathrm{P}$ could differ. Furthermore, plant benefits due to association with AM fungi would vary according to the tree and fungus identity, with similar levels of AM colonisation theoretically resulting in different P-uptake rates for different species (Herre et al. 2007; Maherali 2014; Siqueira and SagginJúnior 2001). Given the multiple and increasingly recalcitrant forms of $\mathrm{P}$ in highly weathered soils, enzyme production, association with AM fungi and a high diversity of root morphological traits, combined could maximize $\mathrm{P}$ uptake (Kong et al. 2014; Li et al. 2017; Zemunik et al. 2015), indicating that in soils with very low $P$ availability, such those in Central Amazon, more than one P-uptake strategy is needed. Ultimately, understanding how root traits vary at the ecosystem level and how they relate to each other is critical to expand our knowledge about $\mathrm{P}$ cycling mechanisms, especially in the context of Plimitation in tropical forests with very high tree diversity.

\section{Conclusions}

In a P-poor tropical forest in Central Amazonia, we show that morphological traits of absorptive fine roots are related to root phosphatase activity. However, these roots are also associated with AM fungi, independent of their morphology. We suggest that: 1) the substantial investment in multiple root P-uptake strategies further emphasises the importance of P-limitation to the function of these forests; 2) mycorrhizal association could have other benefits for plants other than only P-uptake; 
3) the relative abundance of other resources such as water, light, carbon and nitrogen may explain how plants are able to invest resources in multiple P-uptake mechanisms; and 4) the high diversity of tree species and the resulting diversity and combinations of P-uptake strategies makes detecting possible trade-offs between individuals or species challenging, which highlights the importance of ecosystem level estimates (i.e. inability of add up all possible strategies in a meaningful way). Overall, we conclude that because of the many forms that $\mathrm{P}$ is found in Amazon soils and the multiple steps needed to make $P$ available for plants, roots also display a range of adaptations to enhance P-uptake under limitation. The hydrolysis of organic $\mathrm{P}$ by root phosphatase exudation and inorganic P-uptake by AM fungi could be seen as complementary mechanisms contributing to the functioning of this Central Amazon forest, at even very low $\mathrm{P}$ availability.

Acknowledgements The authors would like to thank K. J. Bloomfield for reviewing an earlier version of the manuscript. We thank M. Pires for her help processing the root samples, C. Palheta and the Laboratorio Tematico de Microscopia Optica e Eletronica (LTMOE) at INPA, Manaus for helping with the mycorrhizal colonisation assessment and Dr. M. Liptak on behalf of EnviroScience Co. (https://www.enviroscienceinc.com/) for the donation that funded the purchase of the scanner. We are also thankful to R. Filho and the Laboratorio Tematico de Plantas e Solos (LTSP) at INPA for the soil P fractionation and the Laboratorio de Manejo Florestal (LMF - INPA) for helping with the logistics during the field campaign. This research was supported by the Brazilian National Council for Scientific and Technological Development (CNPq) and UK's Natural Environment Research Council (NERC), grant number NE/L007223/1; PM also acknowledges support from ARC, DP170104091.

\section{Compliance with ethical standards}

Conflict of interest The authors declare that they have no conflict of interest.

Open Access This article is distributed under the terms of the Creative Commons Attribution 4.0 International License (http:// creativecommons.org/licenses/by/4.0/), which permits unrestricted use, distribution, and reproduction in any medium, provided you give appropriate credit to the original author(s) and the source, provide a link to the Creative Commons license, and indicate if changes were made.

Publisher's note Springer Nature remains neutral with regard to jurisdictional claims in published maps and institutional affiliations.

\section{References}

Aerts R (1996) Nutrient resorption from senescing leaves of perennials: are there general patterns? J Ecol 84:597-608

Aerts R (1999) Interspecific competition in natural plant communities: mechanisms, trade-offs and plant-soil feedbacks. J Exp Bot 50:29-37

Aoki M, Fujii K, Kitayama K (2012) Environmental control of root exudation of low-molecular weight organic acids in tropical rainforests. Ecosystems 15:1194-1203. https://doi. org/10.1007/s10021-012-9575-6

Araújo AC (2002) Comparative measurements of carbon dioxide fluxes from two nearby towers in a central Amazonian rainforest: the Manaus LBA site. J Geophys Res 107. https://doi.org/10.1029/2001jd000676.

Bardgett RD, Mommer L, De Vries FT (2014) Going underground: root traits as drivers of ecosystem processes. Trends Ecol Evol 29:692-699. https://doi.org/10.1016/j. tree.2014.10.006

Bates TR, Lynch JP (2001) Root hairs confer a competitive advantage under low phosphorus availability. Plant Soil 236: 243-250

Brundrett MC (2002) Coevolution of roots and mycorrhizas of land plants. New Phytol 154:275-304

Brundrett MC (2009) Mycorrhizal associations and other means of nutrition of vascular plants: understanding the global diversity of host plants by resolving conflicting information and developing reliable means of diagnosis. Plant Soil 320:3777. https://doi.org/10.1007/s11104-008-9877-9

Brundrett MC, Piché Y, Peterson RL (1984) A new method for observing the morphology of vesicular-arbuscular mycorrhizae. Can J Bot 62:2128-2134. https://doi.org/10.1139/b84290

Chen W, Koide RT, Adams TS, DeForest JL, Cheng L, Eissenstat DM (2016) Root morphology and mycorrhizal symbioses together shape nutrient foraging strategies of temperate trees. Proc Natl Acad Sci 113:8741-8746. https://doi.org/10.1073 /pnas. 1601006113

Comas LH, Callahan HS, Midford PE (2014) Patterns in root traits of woody species hosting arbuscular and ectomycorrhizas: implications for the evolution of belowground strategies. Ecol Evol 4:2979-2990. https://doi.org/10.1002/ece3.1147

Cross AF, Schlesinger WH (1995) A literature review and evaluation of the Hedley fractionation: applications to the biogeochemical cycle of soil phosphorus in natural ecosystems. Geoderma 64:197-214

Eissenstat DM (1992) Costs and benefits of constructing roots of small diameter. J Plant Nutr 15:763-782. https://doi. org/10.1080/01904169209364361

Eissenstat DM, Yanai RD (1997) The ecology of root lifespan. Adv Ecol Res 27:1-60

Eissenstat DM, Kucharski JM, Zadworny M, Adams TS, Koide RT (2015) Linking root traits to nutrient foraging in arbuscular mycorrhizal trees in a temperate forest. New Phytol 208:114-124. https://doi.org/10.1111/nph.13451

German DP, Weintraub MN, Grandy AS, Lauber CL, Rinkes ZL, Allison SD (2011) Optimization of hydrolytic and oxidative enzyme methods for ecosystem studies. Soil Biol Biochem 43:1387-1397. https://doi.org/10.1016/j.soilbio.2011.03.017 
Grubb P (1977) Control of forest growth and distribution on wet tropical mountains: with special reference to mineral nutrition. Annu Rev Ecol Syst 8:83-107

Guo D, Xia M, Wei X, Chang W, Liu Y, Wang Z (2008) Anatomical traits associated with absorption and mycorrhizal colonization are linked to root branch order in twenty-three Chinese temperate tree species. New Phytol 180:673-683. https://doi.org/10.1111/j.1469-8137.2008.02573.x

Hayes P, Turner BL, Lambers H, Laliberté E, Bellingham P (2014) Foliar nutrient concentrations and resorption efficiency in plants of contrasting nutrient-acquisition strategies along a 2-million-year dune chronosequence. J Ecol 102:396-410. https://doi.org/10.1111/1365-2745.12196

Herre EA, Mejía LC, Kyllo DA, Rojas E, Maynard Z, Butler A, Van Bael SA (2007) Ecological implications of anti-pathogen effects of tropical fungal endophytes and mycorrhizae. Ecology 88:550-558

Hinsinger P (2001) Bioavailability of soil inorganic P in the rhizosphere as affected by root-induced chemical changes: a review. Plant Soil 237:173-195

Hodge A (2004) The plastic plant: root responses to heterogeneous supplies of nutrients. New Phytol 162:9-24. https://doi. org/10.1111/j.1469-8137.2004.01015.x

Hoeksema JD, Chaudhary VB, Gehring CA, Johnson NC, Karst J, Koide RT, Pringle A, Zabinski C, Bever JD, Moore JC, Wilson GW, Klironomos JN, Umbanhowar J (2010) A meta-analysis of context-dependency in plant response to inoculation with mycorrhizal fungi. Ecol Lett 13:394-407. https://doi.org/10.1111/j.1461-0248.2009.01430.x

Jakobsen I, Rosendahl L (1990) Carbon flow into soil and external hyphae from roots of mycorrhizal cucumber plants. New Phytol 115:77-83

Johnson NC (2010) Resource stoichiometry elucidates the structure and function of arbuscular mycorrhizas across scales. New Phytol 185:631-647. https://doi.org/10.1111/j.14698137.2009.03110.x

Joner EJ, Ravnskov S, Jakobsen I (2000) Arbuscular mycorrhizal phosphate transport under monoxenic conditions using radiolabelled inorganic and organic phosphate. Biotechnol Lett 22:1705-1708

Jones DL, Oburger E (2011) Solubilization of phosphorus by soil microorganisms. In: Phosphorus in action (pp. 169-198). Springer, Berlin, Heidelberg

Kitayama K (2013) The activities of soil and root acid phosphatase in the nine tropical rain forests that differ in phosphorus availability on Mount Kinabalu, Borneo. Plant Soil 367: 215-224. https://doi.org/10.1007/s11104-013-1624-1

Kitayama K, Aiba S-I (2002) Ecosystem structure and productivity of tropical rain forests along altitudinal gradients with contrasting soil phosphorus pools on Mount Kinabalu, Borneo. J Ecol 90:37-51

Kitayama K, Majalap-Lee N, Aiba S-i (2000) Soil phosphorus fractionation and phosphorus-use efficiencies of tropical rainforests along altitudinal gradients of Mount Kinabalu, Borneo. Oecologia 123:342-349

Koide RT (1991) Nutrient supply, nutrient demand and plant response to mycorrhizal infection. New Phytol 117:365-386

Kong D, Ma C, Zhang Q, Li L, Chen X, Zeng H, Guo D (2014) Leading dimensions in absorptive root trait variation across 96 subtropical forest species. New Phytol 203:863-872. https://doi.org/10.1111/nph.12842.
Kong DL, Wang JJ, Kardol P, Wu HF, Zeng H, Deng XB, Deng Y (2016) Economic strategies of plant absorptive roots vary with root diameter. Biogeosciences 13:415-424. https://doi. org/10.5194/bg-13-415-2016

Kong D, Wang J, Zeng H, Liu M, Miao Y, Wu H, Kardol P (2017) The nutrient absorption-transportation hypothesis: optimizing structural traits in absorptive roots. New Phytol 213: $1569-1572$

Laliberte E, Lambers H, Burgess TI, Wright SJ (2015) Phosphorus limitation, soil-borne pathogens and the coexistence of plant species in hyperdiverse forests and shrublands. New Phytol 206:507-521. https://doi.org/10.1111/nph.13203.

Lambers H, Shane MW, Cramer MD, Pearse SJ, Veneklaas EJ (2006) Root structure and functioning for efficient acquisition of phosphorus: matching morphological and physiological traits. Ann Bot 98:693-713. https://doi.org/10.1093 /aob/mcl114

Lambers H, Bishop JG, Hopper SD, Laliberte E, Zuniga-Feest A (2012) Phosphorus-mobilization ecosystem engineering: the roles of cluster roots and carboxylate exudation in young Plimited ecosystems. Ann Bot 110:329-348. https://doi. org/10.1093/aob/mcs130

Lambers H, Hayes PE, Laliberte E, Oliveira RS, Turner BL (2015) Leaf manganese accumulation and phosphorus-acquisition efficiency. Trends Plant Sci 20:83-90. https://doi. org/10.1016/j.tplants.2014.10.007

Li H, Liu B, McCormack ML, Ma Z, Guo D (2017) Diverse belowground resource strategies underlie plant species coexistence and spatial distribution in three grasslands along a precipitation gradient. New Phytol 216:1140-1150. https://doi.org/10.1111/nph.14710

Liu B, Li H, Zhu B, Koide RT, Eissenstat DM, Guo D (2015) Complementarity in nutrient foraging strategies of absorptive fine roots and arbuscular mycorrhizal fungi across 14 coexisting subtropical tree species. New Phytol 208:125136. https://doi.org/10.1111/nph.13434

Lynch JP, Ho MD (2005) Rhizoeconomics: carbon costs of phosphorus acquisition. Plant Soil 269:45-56. https://doi. org/10.1007/s11104-004-1096-4

Maherali H (2014) Is there an association between root architecture and mycorrhizal growth response? New Phytol 204: 192-200. https://doi.org/10.1111/nph.12927

Malhi Y, Baker TR, Phillips OL, Almeida S, Alvarez E, Arroyo L, Chave J, Czimczik CI, Fiore AD, Higuchi N, Killeen TJ, Laurance SG, Laurance WF, Lewis SL, Montoya LMM, Monteagudo A, Neill DA, Vargas PN, Patino S, Pitman NCA, Quesada CA, Salomao R, Silva JNM, Lezama AT, Martinez RV, Terborgh J, Vinceti B, Lloyd J (2004) The above-ground coarse wood productivity of 104 Neotropical forest plots. Glob Chang Biol 10:563-591. https://doi. org/10.1111/j.1529-8817.2003.00778.x

McCormack ML, Dickie IA, Eissenstat DM, Fahey TJ, Fernandez CW, Guo D, Helmisaari HS, Hobbie EA, Iversen CM, Jackson RB, Leppalammi-Kujansuu J, Norby RJ, Phillips RP, Pregitzer KS, Pritchard SG, Rewald B, Zadworny M (2015) Redefining fine roots improves understanding of below-ground contributions to terrestrial biosphere processes. New Phytol 207:505-518. https://doi.org/10.1111 /nph.13363

McGonigle TP, Miller MH, Evans DG, Fairchild GL, Swan JA (1990) A new method which gives an objective measure of 
colonization of roots by vesicular-arbuscular mycorrhizal fungi. New Phytol 115:495-501

Metcalfe DB, Williams M, Aragao LE, da Costa AC, de Almeida SS, Braga AP, Goncalves PH, de Athaydes J, Junior S, Malhi Y, Meir P (2007) A method for extracting plant roots from soil which facilitates rapid sample processing without compromising measurement accuracy. New Phytol 174: 697-703. https://doi.org/10.1111/j.1469-8137.2007.02032.x.

Metcalfe DB, Meir P, Aragão LEOC, da Costa ACL, Braga AP, Gonçalves PHL, de Athaydes Silva Junior J, de Almeida SS, Dawson LA, Malhi Y, Williams M (2008) The effects of water availability on root growth and morphology in an Amazon rainforest. Plant Soil 311:189-199. https://doi. org/10.1007/s11104-008-9670-9

Nasto MK, Alvarez-Clare S, Lekberg Y, Sullivan BW, Townsend AR, Cleveland CC (2014) Interactions among nitrogen fixation and soil phosphorus acquisition strategies in lowland tropical rain forests. Ecol Lett 17:1282-1289. https://doi. org/10.1111/ele.12335

Nasto MK, Osborne BB, Lekberg Y, Asner GP, Balzotti CS, Porder S, Taylor PG, Townsend AR, Cleveland CC (2017) Nutrient acquisition, soil phosphorus partitioning and competition among trees in a lowland tropical rain forest. New Phytol 214:1506-1517. https://doi.org/10.1111/nph.14494

Olander LP, Vitousek PM (2000) Regulation of soil phosphatase and chitinase activity by $\mathrm{N}$ and $\mathrm{P}$ availability. Biogeochemistry 49:175-191

Pan Y, Birdsey RA, Fang J, Houghton R, Kauppi PE, Kurz WA, Phillips OL, Shvidenko A, Lewis SL, Canadell JG, Ciais P, Jackson RB, Pacala SW, McGuire AD, Piao S, Rautiainen A, Sitch S, Hayes D (2011) A large and persistent carbon sink in the world's forests. Science 333:988-993

Pregitzer KS, DeForest JL, Burton AJ, Allen MF, Ruess RW, Hendrick RL (2002) Fine root architecture of nine North American trees. Ecol Monogr 72:293-309

Quesada CA, Lloyd J, Schwarz M, Patiño S, Baker TR, Czimczik C, Fyllas NM, Martinelli L, Nardoto GB, Schmerler J, Santos AJB, Hodnett MG, Herrera R, Luizão FJ, Arneth A, Lloyd G, Dezzeo N, Hilke I, Kuhlmann I, Raessler M, Brand WA, Geilmann H, Moraes Filho JO, Carvalho FP, Araujo Filho RN, Chaves JE, Cruz Junior OF, Pimentel TP, Paiva R (2010) Variations in chemical and physical properties of Amazon forest soils in relation to their genesis. Biogeosciences 7: 1515-1541. https://doi.org/10.5194/bg-7-1515-2010

Quesada CA, Lloyd J, Anderson LO, Fyllas NM, Schwarz M, Czimczik CI (2011) Soils of Amazonia with particular reference to the RAINFOR sites. Biogeosciences 8:1415-1440. https://doi.org/10.5194/bg-8-1415-2011

Quesada CA, Phillips OL, Schwarz M, Czimczik CI, Baker TR, Patiño S, Fyllas NM, Hodnett MG, Herrera R, Almeida S, Alvarez Dávila E, Arneth A, Arroyo L, Chao KJ, Dezzeo N, Erwin T, di Fiore A, Higuchi N, Honorio Coronado E, Jimenez EM, Killeen T, Lezama AT, Lloyd G, LópezGonzález G, Luizão FJ, Malhi Y, Monteagudo A, Neill DA, Núñez Vargas P, Paiva R, Peacock J, Peñuela MC, Peña Cruz A, Pitman N, Priante Filho N, Prieto A, Ramírez H, Rudas A, Salomão R, Santos AJB, Schmerler J, Silva N, Silveira M, Vásquez R, Vieira I, Terborgh J, Lloyd J (2012) Basin-wide variations in Amazon forest structure and function are mediated by both soils and climate. Biogeosciences 9:2203-2246. https://doi.org/10.5194/bg-9-2203-2012
Raghothama KG (1999) Phosphate acquisition. Annu Rev Plant Biol 50:665-693

Raghothama KG, Karthikeyan AS (2005) Phosphate acquisition. Plant Soil 274:37-49. https://doi.org/10.1007/s11104-0042005-6

Richardson AE, Simpson RJ (2011) Soil microorganisms mediating phosphorus availability update on microbial phosphorus. Plant Physiol 156:989-996. https://doi.org/10.1104 /pp.111.175448

Ryan MH, Tibbett M, Edmonds-Tibbett T, Suriyagoda LD, Lambers H, Cawthray GR, Pang J (2012) Carbon trading for phosphorus gain: the balance between rhizosphere carboxylates and arbuscular mycorrhizal symbiosis in plant phosphorus acquisition. Plant Cell Environ 35:2170-2180. https://doi.org/10.1111/j.1365-3040.2012.02547.x

Siqueira J, Saggin-Júnior O (2001) Dependency on arbuscular mycorrhizal fungi and responsiveness of some Brazilian native woody species. Mycorrhiza 11:245-255. https://doi. org/10.1007/s005720100129

Smith SE, Read DJ (2010) Mycorrhizal Symbiosis. Elsevier Science.

Smith SE, Jakobsen I, Gronlund M, Smith FA (2011) Roles of arbuscular mycorrhizas in plant phosphorus nutrition: interactions between pathways of phosphorus uptake in arbuscular mycorrhizal roots have important implications for understanding and manipulating plant phosphorus acquisition. Plant Physiol 156:1050-1057. https://doi.org/10.1104 /pp.111.174581

St John TV (1980) Root size, root hairs and mycorrhizal infection: a re-examination of Baylis's hypothesis with tropical trees. New Phytol 84:483-487

Steidinger BS, Turner BL, Corrales A, Dalling JW, Briones MJ (2015) Variability in potential to exploit different soil organic phosphorus compounds among tropical montane tree species. Funct Ecol 29:121-130. https://doi.org/10.1111/13652435.12325

Team RC (2017) R: a language and environment for statistical computing. 2017. R Foundation for Statistical Computing, Vienna

Tiessen H, Stewart JWB, Cole CV (1984) Pathways of phosphorus transformations in soils of differing pedogenesis. Soil Sci Soc Am J 48:853-858. https://doi.org/10.2136 /sssaj1984.03615995004800040031x.

Treseder KK, Vitousek PM (2001) Effects of soil nutrient availability on investment in acquisition of $\mathrm{N}$ and $\mathrm{P}$ in Hawaiian rain forests. Ecology 82:946-954

Turner BL (2008) Resource partitioning for soil phosphorus: a hypothesis. J Ecol 96:698-702. https://doi.org/10.1111 j.1365-2745.2008.01384.x

Turner BL, Romero TE (2010) Stability of hydrolytic enzyme activity and microbial phosphorus during storage of tropical rain forest soils. Soil Biol Biochem 42:459-465. https://doi. org/10.1016/j.soilbio.2009.11.029

Turner BL, Lambers H, Condron LM, Cramer MD, Leake JR, Richardson AE, Smith SE (2012) Soil microbial biomass and the fate of phosphorus during long-term ecosystem development. Plant Soil 367:225-234. https://doi.org/10.1007 /s11104-012-1493-Z

Ushio M, Fujiki Y, Hidaka A, Kitayama K, Poorter L (2015) Linkage of root physiology and morphology as an adaptation to soil phosphorus impoverishment in tropical montane 
forests. Funct Ecol 29:1235-1245. https://doi.org/10.1111 $/ 1365-2435.12424$

Valverde-Barrantes OJ, Horning AL, Smemo KA, Blackwood CB (2016) Phylogenetically structured traits in root systems influence arbuscular mycorrhizal colonization in woody angiosperms. Plant Soil 404:1-12. https://doi.org/10.1007/s11104016-2820-6

Vance CP, Uhde-Stone C, Allan DL (2003) Phosphorus acquisition and use: critical adaptations by plants for securing a nonrenewable resource. New Phytol 157:423-447

Vitousek PM (2004) Nutrient cycling and limitation: Hawai'i as a model system. Princeton University Press, Princeton

Vitousek PM, Sanford RL (1986) Nutrient cycling in moist tropical forest. Annu Rev Ecol Evol Syst 17:137-167

Vitousek PM, Porder S, Houlton BZ, Chadwick OA (2010) Terrestrial phosphorus limitation: mechanisms, implications and nitrogen-phosphorus interactions. Ecol Appl 20:5-15

Walker TW, Syers JK (1976) The fate of phosphorus during pedogenesis. Geoderma 15:1-19

Warton DI, Wright IJ, Falster DS, Westoby M (2006) Bivariate line-fitting methods for allometry. Biol Rev 81:259-291. https://doi.org/10.1017/S1464793106007007
Warton DI, Duursma RA, Falster DS, Taskinen S (2012) Smatr 3an $\mathrm{R}$ package for estimation and inference about allometric lines. Methods Ecol Evol 3:257-259. https://doi.org/10.1111 /j.2041-210X.2011.00153.x

White PJ, Hammond JP (2008) Phosphorus nutrition of terrestrial plants. In: White PJ, Hammond JP (eds) The ecophysiology of plant-phosphorus interactions. Springer, Netherlands

Wurzburger N, Wright SJ (2015) Fine-root responses to fertilization reveal multiple nutrient limitation in a lowland tropical forest. Ecology 96:2137-2146

Yu H, Chin M, Yuan T, Bian H, Remer LA, Prospero JM, Omar A, Winker D, Yang Y, Zhang Y, Zhang Z, Zhao C (2015) The fertilizing role of African dust in the Amazon rainforest: a first multiyear assessment based on data from cloud-aerosol Lidar and infrared pathfinder satellite observations. Geophys Res Lett 42:1984-1991. https://doi.org/10.1002/2015 g1063040

Zemunik G, Turner BL, Lambers H, Laliberté E (2015) Diversity of plant nutrient-acquisition strategies increases during longterm ecosystem development. Nature Plants 1:15050. https://doi.org/10.1038/nplants.2015.50 